\title{
Unleash the Untaught Learning Competencies through Online, Shareable, and Offline Video Lectures in the Philippines
}

\author{
Sherwin P. Batilantes ${ }^{1}$
}

\begin{tabular}{l} 
ARTICLE INFO \\
\hline Article History: \\
Received 09.09 .2021 \\
Received in revised form \\
10.02 .2022 \\
Accepted \\
Available online 01.01 .2023
\end{tabular}

Available online 01.01.2023

\begin{abstract}
The study aimed to determine the benefits of Project OSO: Online, Shareable, and Offline video lectures to seventh-grade students during the Flipped Classroom implementation to resolve the untaught mathematics learning competencies before the school year ended. The study employed the experimental research design with three groups. Using the cluster random sampling technique, these three groups were selected from the seventh-grade population as respondents and were randomly assigned with the three proposed interventions named Project OSO. These three groups underwent the same set of questionnaires as pre-test and post-test before and after the interventions. These 40item multiple-choice research instruments were evaluated, reviewed and quality assured by an expert panel of evaluators using the conducted pilot testing and the generated Cronbach alpha index. The study's findings revealed that learners' test scores differed significantly among the three groups based on one-way ANOVA. However, the Tukey post hoc test showed that the Flipped Online group differed substantially from the Flipped Shareable and Offline groups. Consequently, Project OSO was considered a valuable resource in the Flipped Classroom implementation and highly recommended for instructing learners when the teacher was out due to school-related functions among these three video lectures platforms. These platforms were the flipped online, flipped shareable, and flipped offline video lectures that the learners could probably learn at their own pace, anytime and anywhere.
\end{abstract}

CTUARA Journal. All rights reserved

Keywords:

Flipped online videos, flipped shareable videos, flipped offline videos, ancillary services, unattained learning competencies

\section{Introduction}

Teachers are facilitators of learning, and the quality of the teacher has the most significant effect on the learner's success (Alawamleh et al., 2020). That is why instructors play an essential role in providing an exciting learning environment (Rebaldo, 2021), such as flipping discussions to help students achieve academically based on their interests and what is most suited for them (Blazar \& Kraft, 2017). However, several factors that influence teachers' performance in their tasks also influence their students' performance (Siachifuwe, 2017). According to Into and Gempes (2018), most school instructors said that heavy workloads and supplementary services in the classroom impacted the country's educational quality. Furthermore, according to Saloviita and Pakarinen (2021), various ancillary services among school teachers sometimes result in a loss of motivation, happiness, and competence, as well as burnout symptoms. Additionally, some investigations have shown that school celebrations, such as a prolonged celebration of an athletic event, had no beneficial impact on students' academic achievement (Billonid et al., 2020).

In addition, school closures due to weather and natural catastrophes, absenteeism, and any other reason for absence (Kuhfeld et al., 2020), and holidays associated with regionally recognized festivals (Gonzales, 2017), all of which have a detrimental impact on students' learning. These are some of the factors that influence teachers' academic achievement, and some hold them accountable for extracurricular activities comparable to sports. According to Bradley (2016), extracurricular activities may seem advantageous at first since students may engage more fully in sports, community service, and even apprenticeships. Unfortunately, the lecture time's adverse effects resulted in learners' initial lack of understanding. Then, Sintema, 2020 seconded this assertion that the quality of learners' academic results in Science, Technology, Engineering, and Mathematics (STEM) was declining due to reduced teaching hours for students, and a lack of connection with teachers when dealing with learning/understanding challenges.

Regardless of all the issues impacting their performance in school, teachers are still guided by DepEd Orders. However, despite all these DepEd Orders, some teachers in any discipline, notably mathematics teachers, continue to be blind and deaf, leaving some topics unachieved in the curriculum guide before the school year closes (Batilantes, 2021). These are the circumstances of public-school teachers who continue to be blind and deaf in addressing neglected learning competencies every school year because they are preoccupied with their obligations as teachers and parents at home. 
As a result, since the anticipated benefits of the spiral progression approach in the Philippine DepEd's K to 12 Program were not fulfilled, all disciplines, including Mathematics, were transformed to a broken spiral approach. Thus, the factors that influence teachers' success as low-performing teachers in their jobs also impact their students' achievement as low-performing learners (Tan, 2017). Nonetheless, the teacher must create an exciting learning environment to attain academic success (Blazar \& Kraft, 2017). Consequently, teachers must constantly enhance their teaching methods by investigating digital technology and modern informatory tools to foster creativity in their classrooms (Kumpan \& Kharlamova, 2019).

Since the factors mentioned above affect teachers' obligations, including learner performances, the researcher found it challenging to ultimately deal with the DepEd's Curriculum Guide (2016). This was why, in this study, the researcher used a true-experimental action research design to examine and recommend remedies to observed gaps in his classroom setting. Furthermore, the researcher became involved in addressing the issue of the untaught least learned skills in Mathematics 7, which happened in the last quarter of the curriculum guide in the context of Probability and Statistics. This content was included in the seventh grade through tenth-grade mathematics curriculum guide (DepEd Mathematics Curriculum Guide, 2016). Countries involved, such as Thailand, Singapore, Ukraine, Latvia, Lithuania, Turkey, Canada, Hong Kong, Spain, and the Philippines, include probability and statistics in the last quarter of their curriculum guide (Batilantes 2021). Since the Probability and Statistics content was taught in the latter quarter of the school year, the researcher had found that it always has a low level of competence in higher grades. Thus, de Silva et al. (2020) confirmed this viewpoint, who said that teachers teaching mathematics often neglect the issue of probability and statistics for various reasons connected to extracurricular responsibilities at school. Consequently, these unattained learning competencies were the least acquired in the higher grades, particularly in grade 10 mathematics, under the content of statistics and probability (Ferrer, 2017).

Similarly, the least-learned competencies emphasized in the Philippine DepEd Regional Mass Training on $\mathrm{K}$ to 12 for Grade-7 teachers included seven (7) of the twelve (12) learning competencies in the final quarter of Mathematics 7 curriculum guide (Temelo \& Sillorequez, 2013). Consequently, the researcher became interested in leveraging Information and Communications Technology (ICT) to appeal to digital native learners by utilizing the Flipped Classroom in flipping the teaching method to his instructions by utilizing the project OSO (Online, Shareable, and Offline) video lectures. Thus, information and communication technology (ICT) supports mathematics teachers in increasing their instructional preparation, teaching-learning techniques, subjective, objective, pedagogical knowledge, and other essential skills. It was also beneficial to students by inspiring and engaging them in their studies, increasing their confidence in their mathematical knowledge, and assisting them in expressing and developing numerous subjective and objective ideas through these teacher-created videos for learning (Nabayra, 2022).

This study's intervention was the Flipped Classroom method utilizing the researcher-made flipped videos or Project OSO. This intervention was used to resolve the existing problems surrounding the untaught least learned competencies comprising the least-learned competencies of learners in the last quarter of the mathematical content. This intervention of having flipped videos for instruction was based on the Cognitive Theory of Multimedia Learning, which states that "it is a constructivist approach to learning, in which multimedia are seen as cognitive tools for knowledge creation rather than information delivery methods" (Mayer, 2014). Likewise, according to Kvon et al. (2019), there were vital notions that would assist educators to comprehend the student's learning in the modern era through these methodologies: Heutagogy (Hase \& Kenyon, 2000), encourages learners to become more self-directed, Peeragogy (Rheingold et al., 2015), focuses on co-learning and co-creating, and Cybergogy (Wang \& Kang, 2006), promotes learner engagement in an online environment.

As opposed to a traditional classroom, a flipped classroom reverses the delivery of information and knowledge acquisition (Abushammala, 2019). The typical responsibilities of teachers and students shifted in this classroom setting, and the class schedule may be modified (Keiler, 2018). Thus, learning activity creates a novel learning experience for learners by generating an individual and cooperative learning environment. According to (Angadi et al., 2019), flipped classroom education enables students to encounter new features outside of class rather than typical review tasks. 'The flipped classroom is an example of pedagogy related to teaching and learning processes of twenty-first-century learners,' says the author (Avery \& Huggan, 2018).

Likewise, flipped classroom models have the potential to help teachers promote more engaging methods to K-12 Math teaching and learning, such as problem-based or inquiry-based approaches (Loizou \& Lee, 2020). 
Similarly, the flipped classroom was associated with significant improvements in learners' mathematical learning performance, and it was beneficial to intermediate-level math learners (Wei et al., 2020). Consequently, the researcher believes that flipped classrooms provide an innovative method to prepare students for the 21st-century workforce. It encourages technology, the media, information and cooperation, engagement, critical thinking, and creativity.

Consequently, this research aimed to evaluate how the Flipped Classrooms approach, which utilized project OSO video lectures, influenced learners' performance in the most neglected and least learned learning competencies in Mathematics 7 throughout the school year. Furthermore, using the true-experimental study design assisted instructors in achieving the learning abilities required in the DepEd curriculum guide without interfering with their responsibilities and obligations as teachers or with ancillary functions in school. As a result, this experimental research study explicitly addressed the following study goals:

1. The pre-test and the post-test learners' performance in Flipped Classroom using Project OSO among the three groups.

2. The significant differences in pre-test and post-test of learners' performance in Flipped Classroom using Project OSO across the three groups.

3. The most effective video lectures utilized in Project OSO for Flipped Classroom implementation.

4. Actions that might be taken to integrate Project OSO into the Flipped Classroom in order to unleash the untaught least learned competencies in mathematics 7.

\section{METHODS}

The researcher used the true-experimental research design (Ariel et al., 2021). The conceptual framework of the research is shown in Fig. 1. The three groups in Flipped Classroom were exposed to various instructional modalities, including Flipped Online, Flipped Shareable, and Flipped Offline video lectures. The respondents were then given a pre-test and a post-test before and after the treatments, using the same research instruments.

The study employed descriptive and inferential analyses (Chanoknath \& Louangrath, 2015) to evaluate Project OSO video lectures as an effective tool in the Flipped Classroom implementation. The same was true that Flipped Classroom intervention was an effective platform as an alternative method of teaching mathematics in addressing current issues of skipped and untaught learning competencies, particularly in the final quarter of Mathematics 7 content.

\section{Participants and other Sources of Data and Information}

In this study, the researcher employed cluster sampling method utilizing a simple random technique to determine the study's potential research participants. One out of the eight (8) sections in Grade 7 at Malay National High School for the school year 2018-2019 was chosen randomly. This Grade 7 - Archimedes class was chosen as the study's respondents; it consists of 60 seventh-grade students, aged 12 to 14 , with 22 males and 38 females. They were divided into three groups, and the members of each group were picked at random using the simple random procedure once again. The same was true when selecting the type of intervention to be used in each group using a simple random approach. The study lasted seven (7) weeks, as mentioned in the fourth quarter learning competency codes in Math 7 under (DepEd's K to 12 Mathematics Curriculum Guide, August 2016). 


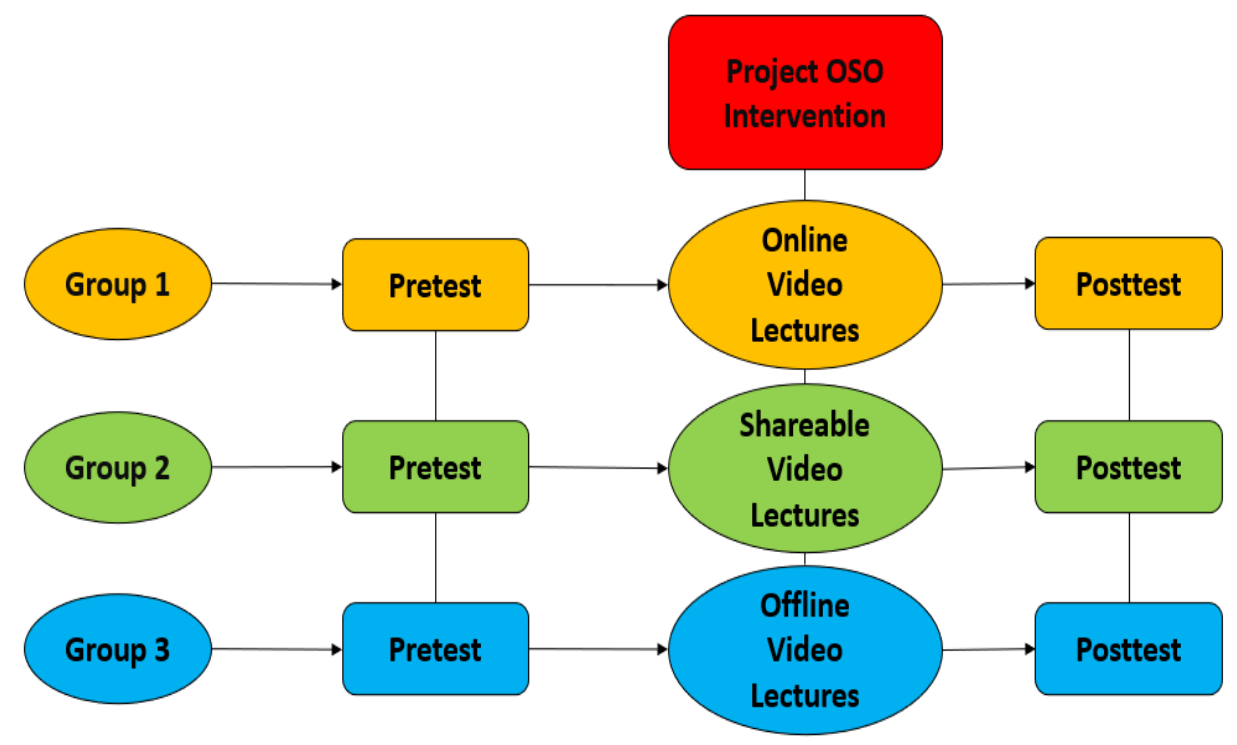

\section{Data Gathering Methods}

Figure 1: The true-experimental research design's conceptual framework

First, the study instrument was created using pilot testing (Fraser et al., 2018) and item analysis (Smriti, 2018) before and after its use. This questionnaire had 40 multiple-choice questions based on the DepEd Curriculum Guide's fourth-quarter Mathematics 7 learning competencies (2016). After that, the researcher enlisted the help of an expert panel of evaluators to analyze the study instrument's validity and reliability, particularly the content and construct feasibility. The researcher then used the final testing instrument among three (3) respondents throughout the pre-test and the post-test administration since the research instruments were found to be valid and reliable throughout the quality assurance methods using Cronbach Alpha and KR 20 to assess reliability. Group 1 underwent Flipped Online video lectures; group 2 underwent the Flipped Shareable video lectures, and group 3 experienced the Flipped Offline video lectures during the Flipped Classroom intervention. These research instruments were administered during the pre-test, and after the intervention was conducted, the same type of research instruments was given during the post-test. Finally, by comparing pre-test scores to post-test scores of all respondents, the statistical analysis used gathered and processed data. When the findings were revealed, the researcher convened a focus group discussion (FGD) with his fellow educators - teaching mathematics, and the school principal to discuss the study's significant findings. The open-ended questions and informal interviews guided the FGD, which sought to identify how Flipped Classrooms utilizing Project OSO video lectures may be implemented in schools, especially for those teachers who are often absent due to school-related functions.

\section{Study's Intervention and Its Procedure}

The researcher used the Flipped Classroom approach with Project OSO video lectures as the researchermade in teaching to address the untaught least learned competencies in Mathematics 7, which occurred in the last quarter of the curriculum guide. Flipped videos are the educational equivalent for teaching with three categories (Online, Shareable, and Offline). This flipped classroom was used if the teachers could not teach their lessons throughout the day. And it may be for an extended time if the teacher was absent to attend schoolrelad events (like seminars, training, and workshops) outside the school premises. 
Table 1. Project OSO (Online, Shareable, \& Offline) Video Lectures in Flipped Classroom

\begin{tabular}{|c|c|c|c|}
\hline Category & $\begin{array}{c}\text { Flipped Online Video } \\
\text { Lectures }\end{array}$ & $\begin{array}{c}\text { Flipped Shareable Video } \\
\text { Lectures }\end{array}$ & $\begin{array}{c}\text { Flipped Offline Video } \\
\text { Lectures }\end{array}$ \\
\hline Description & $\begin{array}{l}\text { These are researcher-made } \\
\text { videos uploaded online, } \\
\text { usually on social media } \\
\text { platforms. } \\
\text { Students with gadgets and } \\
\text { internet connectivity can } \\
\text { access these videos } \\
\text { anytime. }\end{array}$ & $\begin{array}{l}\text { These researcher-made } \\
\text { videos are shared on their } \\
\text { gadgets through Bluetooth, } \\
\text { the SHAREit app, and } \\
\text { more. } \\
\text { Students with gadgets but } \\
\text { no internet connectivity at } \\
\text { home can access these } \\
\text { videos. }\end{array}$ & $\begin{array}{l}\text { The researcher-made } \\
\text { videos are stored offline on } \\
\text { a separate device to be } \\
\text { played and seen by } \\
\text { students. } \\
\text { Students with no device } \\
\text { and internet connectivity } \\
\text { are typical participants of } \\
\text { this intervention. }\end{array}$ \\
\hline Study Location & $\begin{array}{l}\text { Students can watch these } \\
\text { videos at home or in any } \\
\text { place they want. }\end{array}$ & $\begin{array}{l}\text { Students can watch these } \\
\text { videos at home or in any } \\
\text { place they want. }\end{array}$ & $\begin{array}{l}\text { School's e-classroom; } \\
\text { school's computer } \\
\text { laboratory; school's audio- } \\
\text { visual room; classroom } \\
\text { setting using the laptop, } \\
\text { speaker, and projector. }\end{array}$ \\
\hline Device Used & $\begin{array}{l}\text { Mobile phone; laptop, } \\
\text { personal computer; tablet } \\
\text { pc; headset/speaker. }\end{array}$ & $\begin{array}{l}\text { Mobile phone; tablet pc; } \\
\text { headset/speaker }\end{array}$ & $\begin{array}{l}\text { Laptop; projector; } \\
\text { projection screen; e- } \\
\text { classroom computers; } \\
\text { speakers }\end{array}$ \\
\hline
\end{tabular}

They may collaborate with their colleagues online without worrying about the limits.

Collaboration Furthermore, they may collaborate with anybody across the globe, including their peers, even for an extended period of time.
They may not collaborate with their colleagues since they don't have an internet connection to contact them online. However, through phone calls, they can. They may collaborate only with peers through face-toface conversation.

However, the time is limited.
They may collaborate with their colleagues in person, but only for a short period of time.

They may collaborate with anybody in person, but only for a short period of time.

\footnotetext{
These researcher-made video lectures or Project OSO in this Flipped Classroom (Table 2) could help learners learn materials' content while not in the classroom's four corners. Usually, the 15-minute video contains the following lectures anchored in the DepEd Curriculum Guide (2016), activities, quizzes, and some assignments. These videos were quality assured by the school and district Learning Resources Management and Development System (LRMDS) coordinators and some expert panel of evaluators to check the contents, visuals, sounds, and the identified standards set by DepEd in making supplementary videos for instruction. Through the conversion of PowerPoint presentations that include voice recordings and graphic images into moving visuals for instructional purposes were these video lectures in Project OSO. In addition, the researcher utilized Filmora, Audacity, Photoshop Adobe, and Open Broadcaster Software (OBS) to create flipped videos.

These flipped video lectures in Project OSO were the same videos to be disseminated online, shareable and offline platforms. This project OSO includes self-paced activities and performance tasks that need to be accomplished and submitted before returning to school. Activities and assessments, particularly performance tasks, were given to students over extended durations when the teacher was gone in a couple of weeks due to school ancillary functions. This project OSO video lectures in the flipped classroom was undertaken to ensure that learners, even if they were not under the supervision of their teacher. They were made to ensure that learners could study and apply mathematical ideas at their own pace, without the anxiety of learning mathematics in a traditional classroom setting, even without the supervision of a teacher. Hence, the researcher saved these video lectures for future use in his instructions. They were shared with any mathematics' teachers teaching at the same grade level and topics at the school, district, and division levels.
}

Data Analysis 
The study was a quantitative type of research in which the numbers obtained from empirical findings and data collection were tabulated and measured in the appropriate statistical instruments. In this study, the researcher employed a 5\% standard of error with a 95\% confidence in terval to determine whether to consider or reject the null hypothesis. The mean and standard deviation were employed for descriptive analysis (Rocha \& Mondelli, 2020). Since there were three independent groups in research, each with a distinct intervention , and respondents were selected at random with an adequate sample size. Therefore, the one-way ANOVA was used for inferential statistics. Furthermore, the Tukey post hoc test was demonstrated to determine which category of Project OSO was the most effective in conducting Flipped Classroom as an intervention. Moreover, Cohen's $f$ was also calculated to determine the effect size between and within groups that differed significantly. Hence, to generate significant differences, the study used the SPSS ver 2.0 (Allahawiah \& Al Saraireh, 2014).

\section{Scope and Limitation}

The study was school-based research, specifically in the classroom action research where the researcher wanted to find solutions to the observed gaps in the mathematics discipline. The study exclusively employed grade 7 mathematics learning competencies, particularly those in the last quarter where mathematics teachers were frequently neglected to teach before the end of the year. The study's respondents were taken in the parameter exclusively in grade 7 population at Malay National High School, Motag, Malay, Aklan. Since the selected participants were in a group of one section, including 60 students, they were divided into three equal parts through a simple random technique. Some of the selected participants do not fit in a specific category of project OSO. However, there are some of the chosen participants voluntarily and willingly swapped their positions to match in a particular category under study. Until we consequently had all agreed and contented to the selection process. Thus, the researcher continued conducting his study even few of the respondents were interchanged from simple random sampling techniques. Though, at first, they were given equal chances to be selected in a particular category of project OSO, which will be implemented in the Flipped Classroom teaching approach.

\section{Results}

The learner's pre-test performance compared to those exposed in the Flipped Online video lectures $(M=15.85, S D=3.57)$, Flipped Shareable video lectures $(M=15.70, S D=3.72)$, and Flipped Offline video lectures $(M=14.85, S D=4.49)$ was deemed "Unacceptable" because the mean scores were excessively low, being less than half of the mean scores. Table 1 shows descriptions of the reflected scales together with their verbal interpretations. These findings demonstrated that, before the intervention, the three groups had equivalent levels of learner performance. Consequently, even though they have no background in the study's process topics, it was also assumed that the three groups' dispersions of the set of values are normally distributed.

Table 2. Learners' Pre-test Performance in the lipped Classroom Using Project OSO

\begin{tabular}{llll}
\hline \multicolumn{1}{c}{ Project OSO } & $n$ & $\boldsymbol{M}$ & SD \\
\hline Flipped Online Videos Lectures & 20 & 15.85 & 3.57 \\
Flipped Shareable Videos Lectures & 20 & 15.70 & 3.72 \\
Flipped Offline Videos Lectures & 20 & 14.85 & 4.49 \\
\hline
\end{tabular}

Note. The multiple-choice quiz has a maximum score of 40 . Here are the verbal descriptions and the scales that correlate to them. $27.00-40.00$ (Highly Acceptable), 14.00 - 26.99 (Acceptable), and 1.00-13.99 (Unacceptable).

The researcher used the one-way ANOVA to assess the significant differences between and within the three groups of the study using the Flipped Classroom intervention with project OSO. The findings revealed no significant change $(F(2,57)=0.37, p=0.64)$, which was more than the specified standard error of $\alpha=0.05$. These results merely demonstrated that the three groups' dispersions of the set of values were normally distributed. Similarly, the data indicated that they came from a homogeneous group of learners who performed at the same mathematics level. Because of the homogeneity of the research participants, the researcher had started and conducted his study.

Table 3: Pre-test Differences Between and Within Groups in a Flipped Classroom Using Project OSO

\begin{tabular}{cccccc}
\hline Source & $d f$ & $S S$ & $M S$ & $F$ & $p$ \\
\hline Between Groups & 2 & 11.63 & 5.82 & & 0.64 \\
Within Groups & 57 & 889.30 & 15.60 & 0.37 & \\
Total & 59 & 900.93 & & & \\
\hline
\end{tabular}

Note. $p>0.05$ 
The learner's post-test performance when compared to those exposed in the Flipped Online video lectures $(M=30.80, S D=2.91)$ was considered "Highly Acceptable," as compared to the Flipped Shareable video lectures $(M=26.90, S D=2.85)$ and Flipped Offline video lectures $(M=26.05, S D=3.61)$ which were deemed "Acceptable". The verbal description of the mean scores is shown at the bottom of Table 3 . These findings suggested that, after intervention, the Flipped Online video lectures were assessed to strongly influence learners throughout their pedagogies beyond the four corners of the classroom. The same could be said about Flipped Shareable and Flipped Offline video lessons, which might help students enhance their academic performance in mathematics. However, they are less impactful than the Flipped Online video lectures during the conducted intervention. As a result, the researcher concluded that Flipped Classroom employing the project OSO was engaging to learners and may increase their academic performance in mathematics, even when they were not under the supervision of a teacher during their self-paced learning.

Table 4. Learners' Post-test Performance in the lipped Classroom Using Project OSO

\begin{tabular}{llll}
\hline \multicolumn{1}{c}{ Project OSO } & $\boldsymbol{n}$ & $\boldsymbol{M}$ & $\mathrm{SD}$ \\
\hline Flipped Online Videos Lectures & 20 & 30.80 & 2.91 \\
Flipped Shareable Videos Lectures & 20 & 26.90 & 2.85 \\
Flipped Offline Videos Lectures & 20 & 26.05 & 3.61 \\
\hline
\end{tabular}

Note. The multiple-choice quiz has a maximum score of 40 . Here are the verbal descriptions and the scales that correlate to them. 27.00 - 40.00 (Highly Acceptable), 14.00 - 26.99 (Acceptable), and 1.00 - 13.99 (Unacceptable).

The researcher used the one-way ANOVA to evaluate the significant differences between and within the three groups of the study employing the Flipped Classroom intervention with project OSO. Since $(F(2,57)=13.02, p<0.0001)$ was less than the critical standard error of $\alpha=0.05$, the results demons trated a tremendous significant change. The results indicated that the three groups differ significantly between and within themselves. Furthermore, the Tukey post hoc test was calculated to determine which groups in Project OSO substantially impacted the seventh-grade learners when the intervention Flipped Classroom is being implemented. A Tukey post hoc test revealed that the learners' post-test scores in Flipped Online video lectures were significantly higher of $(30.80 \pm 2.91)$ compared to the Flipped Sha reable video lectures $(26.90 \pm$ $2.85, \mathrm{p}<0.01)$ and Flipped Offline video lectures $(26.05 \pm 3.61, p<0.0001)$. There was, however, no statistically significant change between Flipped Shareable and Flipped Offline video lectures ( $p=0.67)$. Moreover, Cohen's $f$ was calculated with $f=0.68$, indicating a large effect size between and within groups. The study results showed that project OSO in Flipped Classroom intervention was an effective alternative teaching material for learners when their teacher was out due to school-related functions. It was strongly advised to use Flipped Online video lectures for instructions that might create a high desire to improve academic performance in mathematics, particularly those neglected learning competencies in the last quarter of the school year.

Table 5: Post-test Differences Between and Within Groups in a Flipped Classroom Using Project OSO

\begin{tabular}{cccccc}
\hline Source & $d f$ & $S S$ & MS & F & $p$ \\
\hline Between Groups & 2 & 256.63 & 128.32 & & $<0.0001$ \\
Within Groups & 57 & 561.95 & 9.86 & 13.02 & \\
Total & 59 & 818.58 & & & \\
\hline
\end{tabular}

Note. ${ }^{* * * *} p<0.0001$

These actions include, but are not limited to, disclosing the study's important results to school administrators in order to garner stakeholder support for broader deployment of this flipped classroom using Project OSO in schools. However, the same was valid for reporting to higher-level authorities, such as district supervisors and education program supervisors in Mathematics, to support teachers' ongoing professional development in accordance with the DepEd's commitment and the principle of life-long learning through Learning Action Cell (LAC) sessions (DepEd Order 35,2016). Thus, through this school-based Learning Action Cell (LAC) and In-service Training (INSET) for public school teachers at the district or division level, the researcher could develop programs to disseminate how this Flipped Classroom with project OSO might be helpful for classroom teachers with ancillary functions in school. Similarly, the researcher might demonstrate how to make flipped videos utilizing internet-based tools, mobile application tools for sharing, and offlinebased tools for long-term educational sustainability development. Finally, since this experimental study was conducted to address the identified issues surrounding the mathematics 7 teaching and learning process, the researcher had to put this intervention, Flipped Classroom with project OSO into realization for future use. 
Likewise, some teachers at higher grade levels may use similar interventions in any discipline. Furthermore, this Flipped Classroom with Project OSO intervention should be used in any quarter to eliminate the untaught least learned skills necessary to the higher-grade learning competencies to achieve the needed learning competencies for learners before the school year closes. This platform might assist teachers in managing their time and provide equal practice to students who were still studying independently even without the teacher's supervision

\section{Conclusions, Discussions, and Implications}

The Flipped Classroom approach, which made use of researcher-created videos named project OSO was used not just to help learners progress in the most neglected learning competencies in mathematics, especially in the last quarter of the curriculum guide. But it was also designed for teachers to reduce the untaught learning competencies before the end of the school year due mainly to various circumstances affecting their responsibilities comparable to ancillary functions in school. Inevitably, that teacher performance influenced student academic performance in school. However, despite all the clamor of public-school teachers regarding the excessive paperwork and systems implemented in a top-down approach, the (DepEd) preserved that all of its conditions were lawful and essential for developing basic education. Thus, public school teachers in the Philippines could design any form of modularized instruction that would allow learners to complete their tasks at home to compensate for the loss of class hours. Likewise, the DepEd Learning Action Cell (LAC) session supported the latter allegation (DepEd Order 35, 2016). As a result, this Flipped Classroom utilizing the project OSO was developed as an intervention in the researcher's identified gaps in his classroom.

Flipped classrooms develop learners to learn more deeply and become responsible for accomplishing their work, creating meaningful engagement with their teacher and classmates, and enhancing their understanding of the materials, especially in Mathematics. Through this method (Flipped Classroom with Project OSO), learners could learn the most neglected learning competencies in the last quarter of the curriculum guide, even if the teachers are not physically present in the classroom. Consequently, learners could grasp prerequisite concepts at the lower grade level before progressing to more complex concepts in the higher grade level. Hence, the goal of the DepEd's K to 12 spiral progressions has been fulfilled since no more untaught learning competencies would be neglected through this flipped class room approach to teaching.

Furthermore, the Flipped Classroom with Project OSO could also be beneficial for teachers to continue their functions in school without affecting their duties as classroom teachers. They could maximize their time and effort by doing some instructional materials for their learners, where they can still use flipped videos for future use. Similarly, the possibilities to achieve all of the learning competencies in the curriculum guide have been met through this flipped classroom to capacitate learners of the prerequisite concepts when they reach the higher grades.

After the completion of this research project, the researcher discovered that the study's findings had some implications for both theory and practice.

1. For the theory. The study's significant findings that flipped classrooms were similar to conventional teaching methods affirmed that this could be applied as a proficiency learning approach requiring each learner to master a subject before advancing to the next level (Ramakrishnan \& Priya, 2016). This Flipped Classroom approach to teaching was not only done outside the school campus. This Flipped Classroom could also be implemented anywhere inside the school site as long as the teacher is not there to deliver instruction - only the recorded video lecture did it. Furthermore, the implementation of this spiral development, especially in mathematics, maybe improved through different instructional procedures comparable to flipped classrooms (Perez et al., 2020). Moreover, Fernandez-Martin et al. (2020) claim that the adoption of Flipped Classroom increased learners' knowledge and practices toward mathematical content and behavior. This strategy also benefited components such as joint effort, independence, selfregulation in education achievements.

2. For the learner's practice. This Flipped Classroom revealed that the effectiveness was comparable to the conventional teaching method. However, it was deemed helpful to learners to learn the most neglected learning competencies in the last quarter of the curriculum guide. Learners will gain confidence due to being equipped with fundamental ideas from the lower grade level when they advance to a higher level. As a result, anxiety about studying mathematics changed from 
having a good attitude towards it, resulting from the spiral progression approach in teaching (Rozgonjuk, 2020). Likewise, learners highly accepted the researcher-made flipped videos since the language used, intonation, and accent is familiar to them compared to the foreign recorded instructional videos taken from any social media platform (Ulker et al., 2021). Hence, the researcher believes that flipped classrooms are an innovative solution to preparing digital native learners for the 21st-century workforce. It fosters technology, the media, knowledge, teamwork, engagement, analytical thought, and innovation.

3. For the teacher's practice. This flipped classrooms are beneficial to teachers for the following reasons: (a) save time by developing essential support instructional materials once preserved, shared, and disseminated to a variety of course or social media platforms for future use; (b) teachers may constantly improve the limitations of their flipped videos, allowing them to identify the instructional video's shortcomings when utilized repeatedly; (c) to guarantee that their ownmissed lessons due to ancillary functions in school do not constitute a loss of learning for learners, particularly the essential learning competencies as they progress to higher grade levels, (d) capable of performing both roles as a regular classroom teaching adviser, and a teacher with ancillary functions in school without compromising obligations in achieving sustainable development.

\section{Recommendations}

The Flipped Classroom with project OSO is an educational approach that requires time and effort on the teacher's part in preparing, recording, and editing a high-quality video presentation to be presented to learners through various teaching modalities. The most well-known scheme by which learners can effectively access this intervention is via social media, such as YouTube, Instagram, and the like. They could also be shared through android phones using mobile applications such as Bluetooth, SHAREit, and so on. Learners could, however, view these filmed videos (flipped classroom) in their respective classrooms or via the school's audiovisual room, e-classroom, or even in their separate audio-visual room throughout the class hour on an offline platform. This solution might include an opportunity for teachers to fill in for them for the short/extended period due to ancillary functions at school such as meetings, seminars, reports, evaluation, and the like. Others could be in the context of an online forum where there are unforeseeable disasters that prohibit learners from attending classes.

Moreover, the purpose of this study was to promote the researcher's advocacy for his whole duration of service, which is "to diminish the untaught least learned competencies in teaching Mathematics." Similarly, as the District Mathematics Coordinator for Secondary Schools, he is accountable for inspiring and motivating those to continue what he has begun. The top research priorities are to share the results for his present school, the Malay National High School in Motag, Malay, Aklan, and his school's district, the Malay District in Aklan. Thus, attaining the goal to finish all the courses in the DepEd's K to 12 Curriculum Guide of 2016 may resolve through this Flipped Classroom with Project OSO approach in teaching due to some teacher's factors affecting their duties. Hence, it is conclusive that Mathematics teachers in Grade 7 should use Flipped Classrooms with Project OSO in their teaching and learning processes. Other grade-level teachers in other disciplines should also apply recorded videos to support instructional materials covering and coping with the fourth quarter's learning competencies by the end of the school year.

Finally, the researcher emanated that he should continue doing research that significantly contributes to his work. Hence, this intervention was an avenue for the learners' academic improvement, especially for teachers in their professional and personal purposes. Likewise, the study's result will be presented to his immediate supervisor regarding the study's remarkable outcome to improve learner's performance in the most neglected learning competencies in the fourth quarter. As a Mathematics coordinator in school and the district, the researcher will conduct focus group discussion (FGD) among Grade 7 Mathematics teachers to endorse Flipped Classroom as their support instruction materials (SIM). Also, the findings will be presented to other school research coordinators during the District In-service Training for Teachers (INSET) to find action on their school's same issues as the researcher had. The researcher will also campaign to his colleagues to value research as the priority target in drafting their Results-based Performance Management System (RPMS) of DepEd. Flipped videos such as Vlogs, PowerPoint presentations aided with audio recordings, and other materials used in Flipped Classroom will be kept in school for future learners' use or teachers' use. The flipped 
videos will be sent for review to the District LRMDS coordinator and included in the Division LRDMS portal to disseminate and utilize the content. However, through this future implementation, there should always exist limitations. Thus, future researchers who wished to probe more about the performed study should resolve the study's limitations as described above. Finally, the researcher intends to publish the study results in local and international scholarly journals and worldwide research paper conferences for other research practitioners and scholars may get insight into what I can give to the global community for researchers.

\section{References}

Abushammala, M.F.M. (2019). The effect of using flipped teaching in project management class for undergraduate students. Journal of Technology and Science Education, 9(1), 41-50. https://doi.org/10.3926/jotse.539

Alawamleh, M., Al-Twait, L.M. \& Al-Saht, G.R. (2020). The effect of online learning on communication between instructors and students during Covid-19 pandemic. Asian Education and Development Studies. https://doi.org/10.1108/AEDS-06-2020-0131

Angadi, N.B., Kavi, A., Shetty, K. \& Hashilkar, N.K. (2019). Effectiveness of flipped classroom as a teachinglearning method among undergraduate medical students - An interventional study. Journal of Education and Health Promotion, 8, 211. https://doi.org/10.4103/jehp.jehp_163_19

Ariel, B., Bland, M. \& Sutherland, A. (2021). Experimental designs. The SAGE Quantitative Research Kit. SAGE Publications Ltd. https://www.researchgate.net/publication/352038974

Avery, K. \& Huggan, C. (2018). The flipped classroom: high school student engagement through 21st centu ry learning. In Education, 24(1), 4-21. https://doi.org/10.37119/ojs2018.v24i1.348

Batilantes, S. (2021). Project VLOGI (Video Lectures on Giving Instructions): Effects on learners' performance in probability and statistics. International Journal of Educational Studies in Mathematics, 8(4), 299-315. https://doi.org/10.17278/ijesim.1004076

Billonid, J., Cabailo, M.T., Dagle, WRM, Godilano, D.M., Kibanoff, K.R. \& Tasic, L.R. (2020). Effects of sports participation on the academic performance of grade 12 students after the K-12 implementation. Scientific and Academic Publishing, 10(2), 41-47. doi:10.5923/j.edu.20201002.03

Blazar, D. \& Kraft, M.A. (2017). Teacher and teaching effects on students' attitudes and behaviors. HHS Public Access, 39(1), 146-170. doi:10.3102/0162373716670260

Bradley, K. (2016). How does shortening the school day affect students? Tempesta Media. https://showcase.tempestamedia.com/how-does-shortening-the-school-day-affect-students-aid-21622/

Chanoknath, S. \& Louangrath, P.I. (2015). Descriptive and inferential statistics. International Journal of Research E Methodology in Social Science, 1(1), 22-35.http://doi.org/10.5281/zenodo.1320727

da Silva, B.G., Borges, Y.M. \& Galo, R. (2020). The use of ludic resources for the teaching of probability and statistics in middle school. Research Society and Development, 9(11), 1-18. https://doi.org/10.33448/rsdv9i11.10672

Department of Education (2016). K to 12 curriculum guide mathematics (Grade 1 to Grade 10). https://www.deped.gov.ph/wp-content/uploads/2019/01/Math-CG_with-tagged-math-equipm ent.pdf

Department of Education (2016). The learning action cell as a K to 12 basic education program school-based continuing professional development strategy for the improvement of teaching and learning. Retreived from https://www.deped.gov.ph/wp-

Fernandez-Martin, F.D., Romero-Rodriguez, J.M., Gomez-Garcia, G. \& Navas-Parejo, M.R. (2020). Impact of the flipped classroom method in the mathematical area: A systematic review. E Mathematics, 8(0), 1-11. https://doi.org/10.3390/math8122162

Ferrer, I.M. (2017). Competency level of grade 10 mathematics teachers in Pangasinan, Philippines. PSU JEMSS, 1(1), 12-15.http://psurj.org/wp-content/uploads/2017/12/2017-JEMS-03.pdf

Fraser, J., Fahlman, D. (Willy), Arscott, J. \& Guillot, I. (2018). Pilot testing for feasibility in a study of student retention and attrition in online undergraduate programs. The International Review of Research in Open and Distributed Learning, 19(1). 260-278.https://doi.org/10.19173/irrodl.v19i1.3326

Gonzales, V. D. (2017). Cultural and economic benefits of festivals to community residents of Batangas, Philippines. Asia Pacific of Education, Arts and Science, 4(2), 14-22. https://research.lpubatangas.edu.ph/wp-content/uploads/2017/06/APJEAS-2017.4.2.02.pdf 
Into, C.A.D. \& Gempes, G. P. (2018). Untold stories of teachers with multiple ancillary functions: A phenomenology of fortitude. Journal of Advances in Humanities and Social Sciences, 4(1), 13-25. https://doi.org/10.20474/jahss-4.1.2.

Keiler, L.S. (2018). Teachers' role and identities in student-centered classroom. International Journal of STEM Education, 5(34), 1-20. https://doi.org/10.1186/s40594-018-0131-6

Kuhfeld, M., Soland, J., Tarawasa, B., Johnson, A., Ruzek, E., \& Liu, J. (2020). Projecting the potential impact of COVID-19 school closure on academic achievement. Educational Research, 49(8), 549-565. https://doi.org/10.3102/0013189X20965918

Kumpan, O. O. \& Kharlamova, L. S. (2019). Implementation of interactive teaching methods in the process of developing professional-communicative proficiency of future pilots. International Journal of Science Annals, 2(1-2), 12-18.https://doi.org/10.26697/ijsa.2019.1-2.02

Kvon, G.M., Vaks, V.B., Kalimullin, A.M., Bayanova, A.R., Shaidullina, A.R., Dolzhikova, A.V. \& Lapidus, N.I. (2017). Developing the informational and digital environment of a university: problem analysis and assessment. EURASIA Journal of Mathematics, Science and Technology Education, 15(10), 1-14. https://doi.org/10.29333/ejmste/109503

Lo, C. K. \& Hew, K. F. (2017). A critical review of flipped classroom challenges in K-12 education: possible solutions and recommendations for future research. Research and Practice in Technology Enhanced Learning, 12(4), 1-22. https://doi.org/10.1186/s41039-016-0044-2

Loizou, M. \& Lee, K. (2020). A flipped classroom model for inquiry-based learning in primary education context. Research in Learning Technology, 28, 1-18. https://doi.org/10.25304/rlt.v28.2287

Mayer, R. (2014). Cognitive theory of multimedia learning. The Cambridge handbook of multimedia learning. Cambridge University Press, 43-71.https://doi.org/10.1017/CBO9781139547369.005

Nabayra, J.N. (2022). Mathematics learning in the new normal through teacher through teacher-created videos: The freshmen university students' experience. International Journal of Arts and Humanities Studies, 2(1), 22-27. https://doi.org/10.32996/bjahs.2022.2.1.4

Perez, J.C., Bongcales, R.C.A. \& Bellen, J.A. (2020). A scoping review on the implementation of the spiral progression approach. Journal of Academic Research, 1(1), 11-22. https://jar.ssu.edu.ph/index.php/JAR/article/view/198

Ramakrishnan, N. \& Priya, J.J. (2016). Effectiveness of flipped classroom in mathematics teaching. International $\begin{array}{llll}\text { Journal of } & \text { Research-Granthaalayah, }\end{array}$ https://doi.org/10.29121/granthaalayah.v4.i10(SE).2016.2469

Rebaldo, M. A. (2021). Achievement of teachers and grades of private junior high school students of West, Aklan, Philippines. ResearchJet Journal of Analysis and Inventions, 2(11), 59-68. https://doi.org/10.17605/OSF.IO/B49ZU

Reingold, H., Danoff, C. J. \& Pierce, C. (2015). The peeragogy handbook. (3rd ed., 1-290). PubDomed and Pierce Press. https://peeragogy.org/Peeragogy.io-3/peeragogy-3-0-beta3.pdf

Rocha, A. V. \& Mondelli, M. F. C. G. (2020). Applicability of the ear measurement for audiological intervention of tinnitus. Brazilian Journal of Otorhinolaryngology, 86(1), 14-22. https://doi.org/10.1016/j.bjorl.2018.07.010

Rozgonjuk, D., Kraav, T., Mikkor, K., Orav-Puurand, K. \& That, K. (2020). Mathematics anxiety among STEM and social sciences students: the roles of mathematics self-efficacy, and deep and surface approach to learning. International Journal of STEM Education, 7(46), 1-11. https://doi.org/10.1186/s40594-020-00246-z

Saloviita, T. \& Pakarinen, E. (2021). Teacher burnout explained: teacher-, students-, and organization-level variables. Teaching and Teacher Education, 97 (103221),1-14. https://doi.org/10.1016/j.tate.2020.103221

Siachifuwe, M. (2017). Teacher based factors influencing academic performance among learners in open learning classes at Twin Palm Secondary School, Lusaka, Zambia. International Journal of Humanities and Social Sciences, 4, 96-101. https://doi.org/10.20431/2349-0381.0412012

Sintema, E. J. (2020). Effect of COVID-19 on the performance of grade 12 students: Implications for STEM education. EURASIA Journal of Mathematics, Science and Technology, 16(7), 1-6. https://doi.org/10.29333/ejmste/7893

Smriti, A. (2018). Item analysis. International Journal of Nursing Science Practice and Research, 4(2), 6-7. https://doi.org/10.37628/ijnspr.v4i2.813 
Tan, J.S.T. (2017). Factors affecting stress among faculty members of public universities in the Philippines: a multiple regression analysis. Internatioal Journal of Psychological Studies. 9(3), 64-78. http://doi.org/10.5539/ijps.v9n3p64

Temelo, D.R.T. \& Sillorequez, E.Y. (2013). Development of training design and materials to enhance grade 7 mathematics teachers' competencies. WVSU Research Journal, 2(2), 32-42. https://ejournals.ph/article.php?id=11857

Ulker, M., Gungor, H. \& Cakiroglu, Y. (2021). The effect of conduction activities with native language and video learning on academic success in teaching. Scientific Research Publishing, 12(5), 1169-1185. https://doi.org/10.4236/ce.2021.125087

Wang, M. J. \& Kang, J. (2006). Cybergogy of engaged learning through information and communication technology: A framework for creating learner engagement. In D. Hung \& M. S. Khine (Eds.), Engaged learning with emerging technologies (pp. 225-253). New York: Springer Publishing. DOI: 10.1007/1-4020-3669-8_11

Wei, X., Cheng, I., Chen, N., ..., Zhai, X. (2020). Effect of the flipped classroom on the mathematics performance of middle school students. Educational Technology Research and Development, 68. https://dx.doi.org/10.1007/s11423-020-09752-x

Yilmaz, C., Bulus, H., Oguztuzun, S., Cihan, M. \& Fidan, C. (2020). The activities of GST isozymes in stomach tissues of female obese patients. Turk J Biochem, 45(6), 883-889.https://doi.org/10.1515/tjb-2020-0235 